\title{
Tunneling Endoscopic Technique Moving through Zenker's Diverticulum
}

\author{
Margarida Flor de Lima Nuno Nunes Vera Costa Santos Maria Antónia Duarte \\ Gastroenterology Department, Hospital do Divino Espírito Santo de Ponta Delgada, Ponta Delgada, Portugal
}

\section{Keywords}

Zenker's diverticulum · Submucosal tunneling technique ·

Dysphagia

\section{Tunelização da submucosa aplicada ao divertículo de Zenker}

\section{Palavras Chave}

Divertículo de Zenker - Técnica de tunelização da submucosa $\cdot$ Disfagia

A 79-year-old male patient presents with intermittent dysphagia to solids, regurgitation, and halitosis. The patient had undergone a Zenker's diverticulum (ZD) septum division 6 years earlier, with recurrence of symptoms over the past 2 years. An upper digestive endoscopy revealed residual diverticulum of approximately $2 \mathrm{~cm}$. A submucosal tunneling endoscopic septum division was performed under general anesthesia with endotracheal intubation, using a transparent cap (DH28GR; Fujifilm, Tokyo, Japan) attached to the tip of the gastroscope and insufflation with carbon dioxide. The submucosa was injected $2 \mathrm{~cm}$

\section{KARGER}

E-Mail karger@karger.com www.karger.com/pig
(C) 2019 Sociedade Portuguesa de Gastrenterologia Published by S. Karger AG, Basel

Karger

Upen access

This article is licensed under the Creative Commons AttributionNonCommercial-NoDerivatives 4.0 International License (CC BYNC-ND) (http://www.karger.com/Services/OpenAccessLicense) Usage and distribution for commercial purposes as well as any distribution of modified material requires written permission. above the septum, and a longitudinal mucosal incision of $1 \mathrm{~cm}$ was made at the tunnel entrance (Fig. 1). A submucosal longitudinal tunnel was created between the mucosal and muscular layers at both sides of the septum (Fig. 2), using a T-Type Hybrid-Knife ${ }^{\circledR}$ (Erbe Elektromedizin, Tübingen, Germany), followed by the dissection of the cricopharyngeal muscle fibers until the normal esophageal muscle was reached. Closure of the mucosal incision was made with hemostatic clips (Instinct ${ }^{\mathrm{TM}}$; Cook Medical, Bloomington, IN, USA) (Fig. 3). The procedure lasted 64 $\mathrm{min}$. There were no adverse events observed, and the patient started liquid diet $24 \mathrm{~h}$ later. Intravenous antibiotics were administered before the procedure and were continued for 2 days postoperatively. Proton-pump inhibitor treatment was initiated. The patient was discharged $48 \mathrm{~h}$ after the procedure. After 8 months, there was complete resolution of the initial symptoms.

$\mathrm{ZD}$ is a rare clinical finding, often manifested by symptoms such as dysphagia and regurgitation. If symptomatic, local treatment of $\mathrm{ZD}$ is recommended [1]. The development of several flexible endoscopic techniques demonstrates variable success rates and a recurrence rate of at least $10 \%$, associated with the incomplete dissection of the diverticulum [2]. 


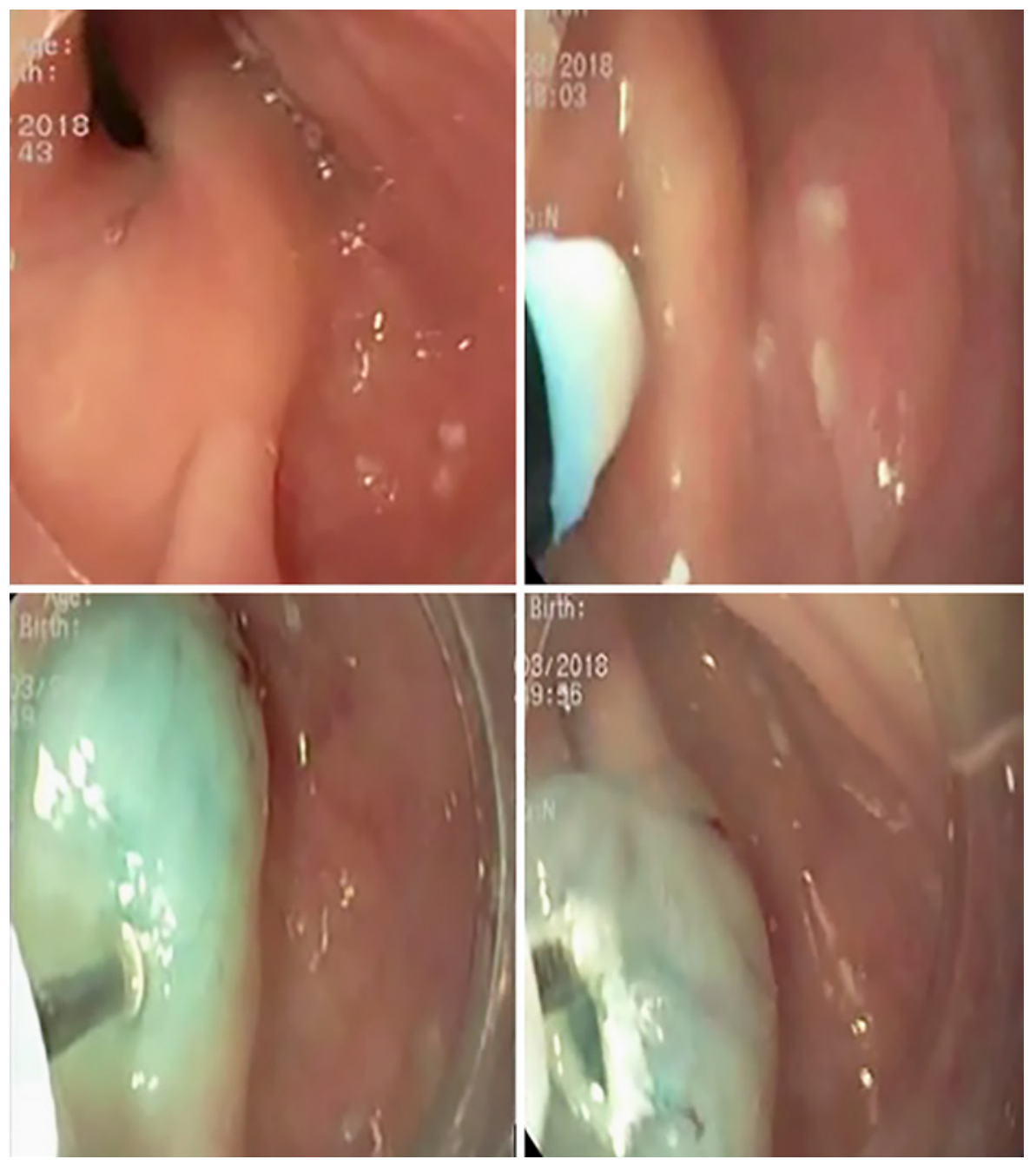

Fig. 1. Identification of $\mathrm{ZD}$, injection of the submucosal layer, and incision of the mucosa $2 \mathrm{~cm}$ above the septum.
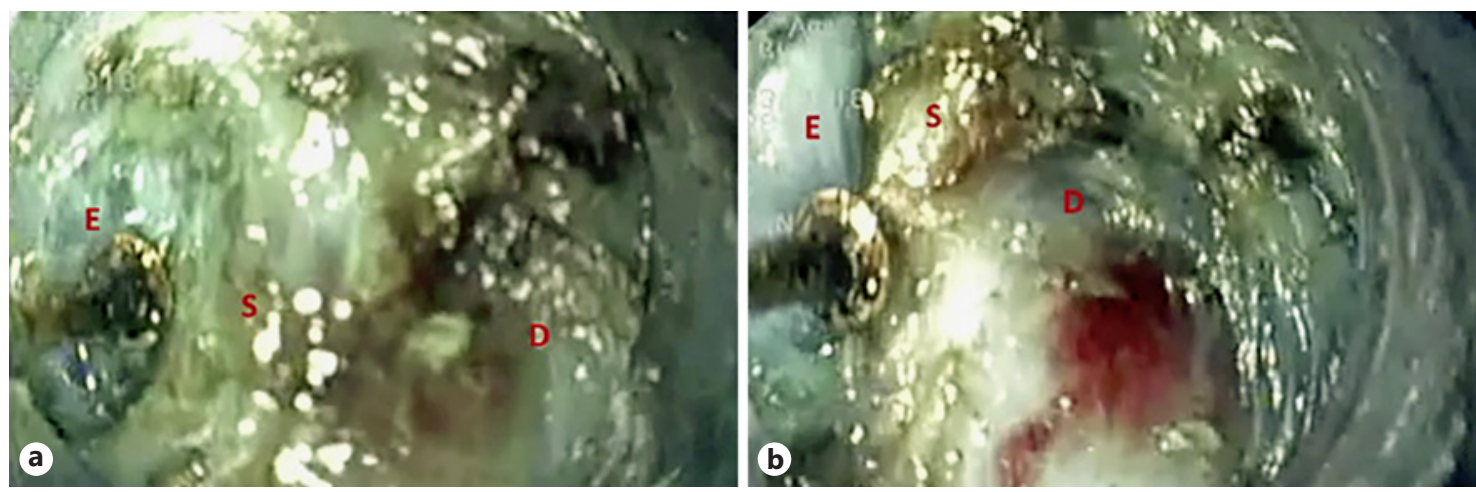

Fig. 2. a Dissection of submucosal fibers on the esophageal side of the septum. b Dissection of the septum. E, esophageal side of the septum; D, diverticular side of the septum; $S$, septum of the diverticulum. 

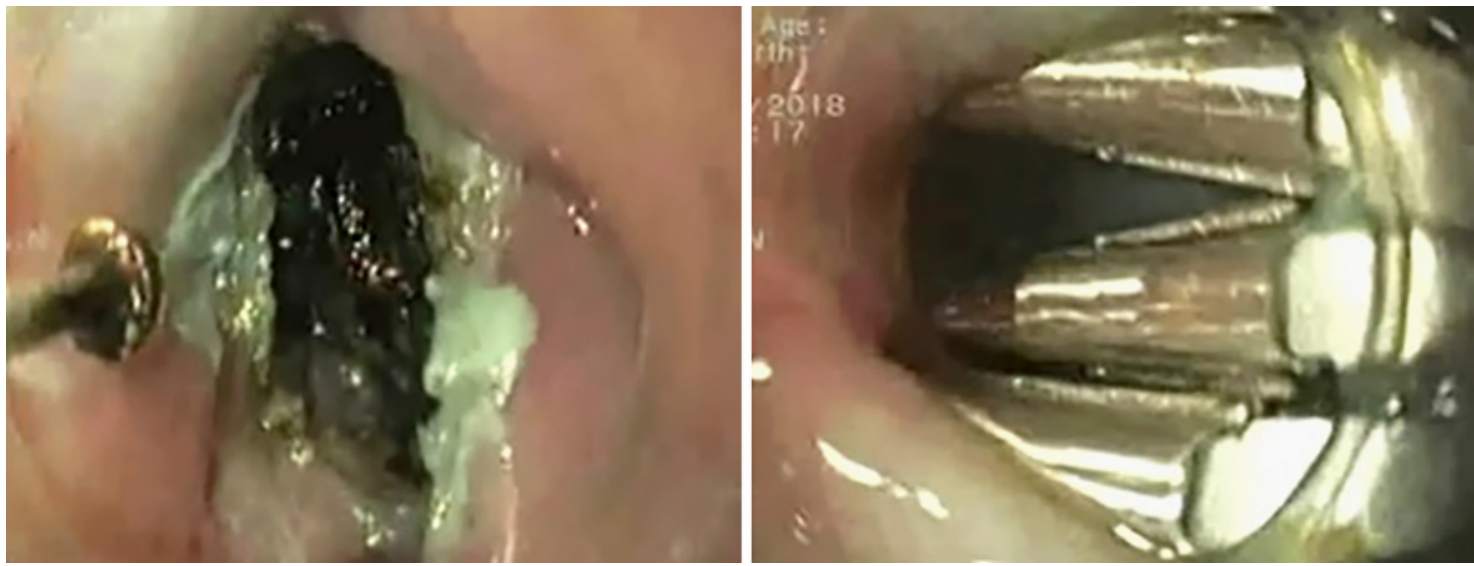

Fig. 3. Closure of the mucosal incision site with hemostatic clips.

The tunneling endoscopic technique, after being developed for the treatment of achalasia, has been applied to other areas of intervention such as ZD [3,4]. The tunneling technique aims to provide a complete myotomy of the septum, maintaining the mucosal integrity and potentially reducing the recurrence rate, although its efficacy is still restricted to case reports and small series. This method is also limited by local expertise. Further studies are needed before general application $[4,5]$.

\section{Statement of Ethics}

This study did not require informed consent nor review/approval by the appropriate ethics committee.

\section{Disclosure Statement}

The authors have no conflicts of interest to declare.

\section{References}

1 Law R, Katzka DA, Baron TH. Zenker's Diverticulum. Clin Gastroenterol Hepatol. 2014 Nov;12(11):1773-82.

2 Ishaq S, Sultan H, Siau K, Kuwai T, Mulder CJ, Neumann H. New and emerging techniques for endoscopic treatment of Zenker's diverticulum: state-of-the-art review. Dig Endosc. 2018 Jul;30(4):449-60.

3 Inoue H, Minami H, Kobayashi Y, Sato Y, Kaga M, Suzuki M, et al. Peroral endoscopic myotomy (POEM) for esophageal achalasia. Endoscopy. 2010 Apr;42(4):265-71.
4 Li QL, Chen WF, Zhang XC, Cai MY, Zhang YQ, Hu JW, et al. Submucosal tunneling endoscopic septum division: a novel technique for treating Zenker's diverticulum. Gastroenterology. 2016 Dec;151(6):1071-4.

5 Brewer Gutierrez OI, Moran R, Yang J, Sanaei O, Kalloo AN, Kumbhari V, et al. Successful single-session cricopharyngeal and Zenker's diverticulum peroral endoscopic myotomy. Endoscopy. 2018 Aug;50(8):E220-1. 